\title{
The Effects of Oil Price Shocks on Economic Growth of Oil Exporting Countries: A Case of Six OPEC Economies
}

\author{
Monesa $^{1}$, Laila Taskeen Qazi ${ }^{2}$
}

\begin{abstract}
The main objective of this study is to empirically investigate the effects of oil price shocks on economic growth of oil exporting countries. This research examines the impacts of oil price shocks on GDP growth, inflation, investment and the exchange rate of six OPEC economies using annual data from 1980 to 2013. The study uses Augmented Dickey Fuller (ADF) to establish Stationarity of the time series and applies Vector Autoregressive (VARX) model with Ordinary Least Squares (OLS) model to estimate the effects of oil price shocks on economic growth of the six OPEC countries during the research period. The results of the study indicates a statistically significant negative impact of oil shock on GDP growth of Algeria, a statistically significant positive impact of oil price shock on GDP growth of Venezuela, a statistically significant positive impact of oil shock on inflation rate of Iran and a statistically significant negative impact of oil shock on inflation rate of Venezuela, whereas, results for rest of the variables and countries were found statistically insignificant.
\end{abstract}

\section{Introduction}

Economists have considered oil price shocks due to significant effects on macroeconomic variables. Various negative and positive oil price fluctuations have been experienced by the world economy. Fluctuations in oil prices have been a main cause of disturbance in economic activities of the oil exporting economies because oil sector plays an important role in production and exports. Since the oil sector of oil exporting countries is subject to uncertainty in oil markets of the world; therefore, the macroeconomic variables have been affected significantly by fluctuations in oil price.

Oil price changes play a vital role in fluctuation of real GDP (Ito, 2008, 2010; Umar \& Abdul Hakeem, 2010). However, Olomola (2006) argued that there had been no impact of oil price shocks on output growth. A significant relationship exists between the exchange rate and oil price movements (Nikbakht, 2010). High oil prices lead to real exchange rate appreciation of the oil exporting economies, making local products more expensive and increasing the demand for foreign products; as a result the agricultural and manufacturing sectors of oil exporting countries suffer

1 Student, Institute of Management Sciences

2 Lecturer, Institute of Management Sciences 
which in turn gives rise to Dutch disease and thus, has adverse effects on economic growth (Olomola, 2006). Oil price fluctuations lead to uncertainty in inflation rate which adversely affect the economic growth of oil exporting countries (Arinze, 2011; Bouchaour \& Al-Zeaud, 2012; Shaari, Hussain \& Abdullah, 2012). However, Olomola (2006) argued that there has been no impact of oil price shocks on inflation. An oil price change plays a vital role in changes of government expenditure. A significant positive link exists between government expenditure and oil price (Lorde, Jackman \& Thomas, 2009; Garkaz, Azma \& Jafari, 2012) while Markwardt (2009) found that there is a marginal effect of fluctuation in oil price on the real government expenditures.

The empirical studies related to impacts of oil price fluctuations on the macroeconomic variables are mostly focused on the oil importing economies (Muhammad, 2010; Jawad, 2013); other studies are focused on industrialized countries (Jimenez, Rodriguez \& Sanchez, 2005). However, other studies have focused on the effects of oil price changes on macroeconomic variables of the individual oil exporting economies like in the work of Olomola (2006), Ito (2008 and 2010), Farzanegan and Markwardt (2009), Lorde, Jackman and Thomas (2009), Umar and AbdulHakeem (2010), Mordi and Adebiyi (2010), Mehrara, Maki and Tavakolian (2010), Mendoza and Vera (2010), Mehrara (2011), Arinze (2011), Eltejaei and Afzali (2012 ), Bouchaour and Al-Zeaud (2012), Adedokun (2012), Garkaz, Azma and Jafari (2012), Shaari, Hussain and Abdullah (2012), Rezazadehkarsalari, Haghiri, and Behrooznia (2013); only few researches have been conducted on impact of oil shock on group of oil exporting countries such as the work of Mehrara (2008), Lorde, Jackman and Thomas (2009), Nikbakht (2010), Monjazeb, Souri and Shahabi (2013). Therefore this study aimed at filling this gap; the specific objective of the research was to estimate the impacts of oil shocks on economic/output growth of oil exporting economies.

In this regard the study strived to determine whether oil price shocks affect GDP growth, inflation rate, investment rate and foreign exchange rates of oil exporting countries. The research has been conducted on six OPEC countries including Algeria, Kuwait, Iran, Venezuela, Saudi Arabia and Nigeria over the period 1980 to 2013. In order to empirically estimate the abovementioned relationships; in the next section past literature has been reviewed which is then followed by the analytical part of the research beginning with testing the time series Stationarity through Augmented Dickey Fuller (ADF) test, followed by measuring oil price shocks through squared errors of Ordinary Least Square (OLS) model and finally applying the Vector Autoregessive (VAR) to measure oil shocks effects on inflation, GDP growth, exchange rate and investment rate. 


\section{Literature Review}

According to Schirber (2009) oil prices are not stable; the varying political situations, activities of Organization of the Petroleum Exporting Countries (OPEC), changes in oil demand and supply invite significant oil price fluctuations. The world economy is suffering from high oil prices because oil is the central factor of production of the world economy. Oil price increase not only adds costs at the pump, but also the cost of products (goods and services). It is worth noting that political instability, increased demand from countries and shrinking supply subjects the word economy to oil price shocks.

Fluctuations in oil price have significant effects on economic activity of a country (Eltejaei \& Afzali, 2012). However the impact of these fluctuations is expected to vary in oil importing and exporting economies, this can be explained by the fact that oil exporting countries should consider the rise in oil price as a good news while oil importing countries should consider it as a bad news and vice versa (Ghalayini , 2011). In oil exporting countries, the oil sector constitutes a crucial part of exports and government revenues. For the last four decades the world oil market has been very vulnerable, therefore understanding how and to what extent the economic growth in oil exporting countries is affected by positive and negative shocks plays a vital role in economic policy makings (Mehrara \& Dehkarsalari, 2011).

A number of research studies investigated the link between oil price changes and macro economic variables; but most of the studies are conducted on oil importing economies like Muhammad (2010) analyzed the link between volatility of oil price and the export earning in Pakistan over the period 1975 to 2008. Moreover, Jawad (2013) investigated the relationship between oil price volatility and the economic growth in Pakistan over the period 1973 to 2011. Other studies focused on industrialized countries. Jimenez Rodriguez and Sanchez (2005) examined the impact of oil shocks on the real GDP growth with reference to OECD countries. In addition, significant amount of literature is available supporting the concept of oil price fluctuations and its impact on macro economic variables in oil exporting country or group of countries.

Mehrara (2008) estimated the asymmetric effects of oil revenues on output growth in 13 oil exporting economies, namely; Colombia, Algeria, Ecuador, Qatar, Indonesia, Libya, Iran, Kuwait, Mexico, United Arab Emirates, Nigeria, Saudi Arabia and Venezuela using annual data during the period 1965 to 2004 and applying two different oil shocks measures and a dynamic panel framework, the researcher concluded that positive oil shocks were dominated by negative shocks. The adverse effects of oil bust on economic growth were more long lasting while a limited role was played by oil booms in stimulating economic growth. 
In the case of Venezuela, Mendoza and Vera (2010) following Hamilton (2003), Lee et al. (1995) and Mork (1989) investigated the asymmetric effects of oil price shocks on output growth using (Generalized Autoregressive Conditional Heteroskedasticity) GARCH model during the period 1984 to 2008. The results showed a significant positive effect of oil price shocks on economic growth. Moreover, the results suggested that the economy of Venezuela was more responsive to positive oil price shocks as compared to negative shocks.

Berument, Ceylan and Dogan (2010) investigated the impact of oil shocks on economic growth in the selected Middle East and North African (MENA) economies and used Vector Autoregressive (VAR) model. As MENA is composed of both oil importing and oil exporting countries, it was found that positive oil shocks had significant positive impact on economic growth of the oil exporting economies (Algeria, Iraq, Iran, Kuwait, Oman, Libya, Syria, Qatar, and the United Arab Emirates) and vice versa. Whereas, there have been no significant effect of oil price shock on economic growth of oil importing countries (Bahrain, Egypt, Djibouti, Jordan, Israel, Tunisia and Morocco). For finding the effect of oil shocks on latter set of countries, the positive oil shocks were further decomposed to oil supply and oil demand shocks. It was suggested that output decreased with positive oil supply shocks while the output increased with positive oil demand shocks. When the exercise was repeated for oil exporting countries, these countries output increased regardless of whether oil price increases were associated with oil supply shocks or oil demand shocks.

In case of Iran, Mehrara, Maki and Tavakolian (2010) examined the asymmetric effects of oil revenues and economic growth during the period 1959 to 2007 applying the threshold error correction approach. The authors concluded that output growth was more responsive to low oil revenue regimes than to high oil revenue regimes. The threshold of oil revenues was $37 \%$, in a way that when growth rate of oil revenue was less than $37 \%$ (in regimes of low or moderate oil revenues), the economic growth was positively affected by oil revenue, but when growth rate of oil revenue was greater than $37 \%$ (in regimes of high oil revenues), there was no significant impact of oil revenues on output growth. Moreover, Mehrara (2011) and Rezazadehkarsalari, Haghiri, and Behrooznia (2013) estimated the asymmetric impacts of oil shocks on economic growth. Mehrara (2011) using Gregory and Hansen Cointegration test during the period 19602006 concluded that the long run estimations results indicated a negative relationship between oil revenue and production level and the findings were in line with resource course or Dutch disease in countries that are highly dependent on natural resources. While, the short run estimations results indicated that oil shocks have had a significant effect on economic growth, but the impact of negative oil shocks were found to be more long lasting and much stronger as compared to the impact of positive oil price shocks. 
In addition, negative oil shocks had adverse effects on output growth while a limited role was played by positive oil shocks in stimulating economic growth. Moreover, the output growth was more responsive to negative oil shocks than to positive oil shocks. Similarly, Rezazadehkarsalari, Haghiri, and Behrooznia (2013) using Hodrick Prescott filtering to separate negative shocks from positive shocks during the period 1960 to 2010. Their short run estimation results were identical to that of the former study; that economic growth was significantly affected by oil shocks, however; the effects of negative shocks were found much stronger than positive shocks.

In case of Nigeria, Adedokun (2012) studied the effect of oil export revenue and the output growth over the period 1975 - 2009 using Error Correction Model (ECM). The researcher found a significant positive effect of oil revenue on economic growth not only in the short term, but also in the long term. Monjazeb, Souri and Shahabi (2013) studied the link between oil price shocks and output growth of oil exporting economies using the annual data during the period of 1990 to 2009 for 26 oil exporting countries, namely; America, Australia, Bangladesh, Belgium, Brazil, Britain, Canada, Denmark, Egypt, Germany, France, Indonesia, India, Italy, Iran, Japan, Kenya, Kazakhstan, Malaysia, Norway, Mexico, Netherlands, Sweden, Singapore, Thailand and Venezuela applying the panel data regression model with both random and fixed method. The result indicated that positive oil price shocks have had a significant positive impact on GDP growth of oil exporting countries and vice versa while the fixed effects was different for the countries selected.

In case of Russia, Ito (2008) and Ito (2010) investigated the effect of oil prices on real GDP and the inflation level. In former study the author used Vector Autoregressive (VAR) model over the period 1995 to 2007 and concluded that the real GDP and inflation responded positively to increase in oil price. In later study, over the period 1997 - 2007 and using Vector Error Correction (VEC) approach the author came up with identical result; that the real GDP responds by $0.25 \%$ while inflation responds by $0.36 \%$ to a $1 \%$ oil prices increase over the next 12 quarters.

Samimi and Shahryar (2009) studied the effect of oil shocks on inflation and output in six OPEC members, namely Iran, Nigeria, Venezuela, Saudi Arabia, Indonesia and Kuwait using yearly data from 1970 to 2005 and applying structural vector autoregressive (SVAR) method. The results indicated that in long run, the impact of oil shocks on the real GDP growth was positive for all the economies, but not Kuwait. In Kuwait, this impact was negative in the long run, but positive in the short run. The real GDP was positively affected by supply side shocks in all countries and for Iran, Saudi Arabia and Kuwait; in long run, this impact was more permanent as compared to others. In long run, there was a more positive and permanent impact of demand side shock on inflation as compared to supply side shocks. 
In case of Nigeria, Arinze (2011) estimated the effect of oil price on economy using simple regression analysis to find the impact of oil price on inflation rate. The study implied a significant positive effect of petroleum price and inflation. In case of Malaysia, Shaari, Hussain and Abdullah (2012) studied the relationship between oil shocks on inflation using monthly data over the period 2005- 2011 and applying Granger Causality and VAR-VECM model. The results indicated that inflation was affected by crude oil prices. Changes in crude oil price had led to changes in inflation.

Nikbakht (2010) using monthly panel of seven OPEC economies namely, Indonesia, Algeria, Nigeria, Kuwait, Iran, Venezuela and Saudi Arabia over the period $2000-2007$ found the real oil prices as the main cause of real exchange rate movements. Moreover, there was a long run relationship between real exchange rates and real oil prices.

Nigeria, Mordi and Adebiyi (2010) estimated the effect of oil shocks on output and inflation using monthly data during the period 1999 to 2008 and applying structural VAR model. The results of the study indicated that there was an asymmetric effect of oil shocks on output, exchange rate and price. And these variables were more responsive to negative oil price shocks than to positive oil price shocks.

Lorde, Jackman and Thomas (2009) investigated the impacts of oil price changes in case of Trinidad and Tobago. Applying Vector Autoregressive (VAR) model, the results indicated a significant positive effect of positive oil shocks on output, price level, exchange rate, government revenue and gross investment. The exchange rate appreciation was indicative of Dutch disease.

Garkaz, Azma and Jafari (2012) investigated the impact of oil revenues in government expenditure in Iran over the period 1996 to 2007 applying Wavelet analysis approach. During long term period, a strong positive and significant relationship was reported.

Olomola (2006) examined the effect of oil shock in Nigeria on the aggregate economic activity, namely inflation, output, money supply and the real exchange rate using quarterly data over the period 1970 - 2003 and applying Vector Autoregressive (VAR) method. Contrary to previous research findings, the results of this study indicated that there had been no effect of oil price shocks on inflation and output in Nigeria while a significant relationship existed between the real exchange rate and the oil price shocks. Moreover, oil price shock was considered as a significant determinant of real exchange rates and in long run the money supply, while it was not the oil price itself but rather the money supply that affected Nigerian output growth. Therefore, this finding supported the previous researches that monetary policy responds to the 
oil shocks. In addition, Umar and AbdulHakeem (2010) examined the impact of oil price shocks on four macroeconomic indicators, namely, the real GDP, money supply, unemployment and consumer price index using Vector Autoregressive (VAR) model. The results indicated significant effect of oil shocks on all the variables, with the exception of consumer price index.

Bouchaour and Al-Zeaud (2012) studied the effect of oil price fluctuations on Algerian macroeconomics applying a Vector Error Correction Model (VECM) during the period 1980-2011. The key results that emerged from the study were (a) the short term results indicated no significant effect of oil prices on most of the variables, with the exception that they had a negative effect on the real effective exchange rate and a positive effect on inflation rate. (b) the long term results indicated a significant positive effect of oil prices on real GDP and inflation while there was a negative impact of oil prices on unemployment and the real effective exchange rate. (c) oil prices had no impact on money supply.

Eltejaei and Afzali (2012) in Iran, estimated the asymmetric effects of oil price and revenues on growth rates of Gross Domestic Product (GDP), Consumer Price Index (CPI), Government Capital and Current Expenditures using Structural VAR model on quarterly data during the period 1990 to 2008 and found that the effects of positive shocks which increased economic growth had been much weaker than the effects of negative shocks that decreased economic growth. In addition, growth rate of Government current and capital expenditures, and inflation showed an asymmetric response to both negative and positive shocks.

On the other hand, Farzanegan and Markwardt (2009) examined the asymmetric impacts of oil shocks on Inflation, Industrial growth rate, the real effective exchange rate and real government expenditure using Vector Autoregressive (VAR) approach. The key findings that emerged from this paper were: (1) both negative and positive oil price shocks significantly increased inflation. (2) positive oil shocks led to appreciation of exchange rate which indicated the "Dutch Disease" syndrome while negative oil shocks led to depreciation of exchange rate. (3) industrial growth rate (real output) responds negatively to negative oil shocks. (4) only a marginal effect of oil price fluctuations on real government expenditures was found.

The findings from literature review indicate that there is huge amount of work done on the relationship between oil price shocks and macroeconomic variables for individual oil exporting countries. Since very limited studies yet exist on effects of oil price shocks on macroeconomic variables for a group of oil exporting countries. To fill this gap, this research tends to analyze the link between oil shocks and key macroeconomic variables for six members of Organization of the Petroleum Exporting 
Countries (OPEC). The next section describes the methodology of the study.

\section{Methodology}

As the research is based on oil exporting OPEC countries, out of the population of twelve listed OPEC members only six countries have been taken as sample in order to investigate the relationship between oil price shocks and economic growth. These six countries namely Algeria, Iran, Kuwait and Saudi Arabia have been taken from Middle East \& North Africa (MENA) region; Nigeria has been taken from Sub-Saharan Africa region while Venezuela has been taken from Latin America \& Caribbean region. The reason for selecting these six countries is that the data on macroeconomic variables is available only for these economies while for other countries the required data on some variables was not available. Table 1 below presents the summary of OPEC members.

Table 1: Member States of OPEC

\begin{tabular}{|l|l|l|l|}
\hline S.No & Country & Region & Joined OPEC \\
\hline 1 & Algeria & Africa & 1969 \\
\hline 2 & Angola & Africa & 2007 \\
\hline 3 & Ecuador & South America & 2007 \\
\hline 4 & Iran & Middle East & 1960 \\
\hline 5 & Iraq & Middle East & 1960 \\
\hline 6 & Kuwait & Middle East & 1960 \\
\hline 7 & Libya & Africa & 1962 \\
\hline 8 & Nigeria & Africa & 1971 \\
\hline 9 & Qatar & Middle East & 1961 \\
\hline 10 & Saudi Arabia & Middle East & 1960 \\
\hline 11 & United Arab Emirates & Middle East & 1967 \\
\hline 12 & Venezuela & South America & 1960 \\
\hline
\end{tabular}

Only secondary data is used in compilation of this research. The 33 years (19802013) historical data of macroeconomic indicators (inflation, GDP growth rate, investment and exchange rate) of the six mentioned countries is extracted from reliable websites. The data about GDP growth (annual percentage of GDP), inflation (annual percentage of consumer prices) and official exchange rate (LCU per US $\$$ rate, period average) is obtained from World Development Indicators (WDI) while data about investment (percentage of GDP) and oil price (Crude Oil Spot Price Averages) is obtained from Economy Watch. 
The five dependent variables of the study include oil price shocks, inflation rate, GDP growth, exchange rate and investment rate. Each of these has been elaborated below,

GDP growth: It is the measure of economic growth. The amount of goods and services that are produced in an economy over time is called the output/economic growth of that country (Weil, 2009).

Inflation: A sustained rise in the general price level of products (goods and services) over time in an economy is called inflation (Curwen, 1976).

Investment: Radcliffe (1996) has defined investment as the production of newly produced physical things like houses, machinery, factories and inventories of goods.

Exchange rate: The price of currency of one country in terms of another country's currency is called exchange rate (Tauline, 2008).

The independent variable of the study is the oil price shocks described below,

Oil price shocks: A sudden or abrupt change, either decrease or increase is referred as an oil shock. These shocks have been estimated using Ordinary Least Squares model (OLS). The autoregressive OLS model of oil prices has been employed using first lag and the squared residual of the model are treated as oil shocks. In this research oil price shocks have been measured by employing the following autoregressive model.

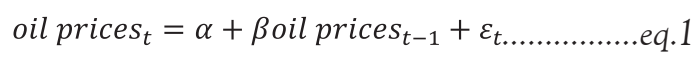

Where, $\alpha$ is the constant, $\beta$ is the coefficient of oil prices at lag 1 and $\varepsilon_{t}$ is the error in time $t$. This autoregressive model provides oil shocks in the form of squared error $\varepsilon_{t}^{2}$.

Using the variables described above, following research hypotheses have been developed.

\subsection{Research Hypotheses}

The study strives to test following research hypotheses,

H1: Oil price shocks affect GDP growth of oil exporting countries.

H2: Oil price shocks affect inflation rate of oil exporting countries.

H3: Oil price shocks affect investment rate of oil exporting countries.

H4: Oil price shocks affect the exchange rates of oil exporting countries. 


\subsection{Normalization}

For analysis purpose the study employed returns instead of prices, the process of converting prices into returns is called normalization of financial data. Normalization basically involves measuring of all variables in a comparable metric that enables the evaluation of logical relationship among two or more variables despite originating from the price series of unequal values. In this study Log returns have been calculated at time $t, t-1$ by employing the following formula.

$$
R_{t}=\log \left(\frac{p_{t}}{p_{t-1}}\right) \ldots \ldots \ldots \ldots \text {....... } 2
$$

Where $R_{t}$ is the log returns at time $\mathrm{t}, p_{t}$ is the price at time $\mathrm{t}$ and $p_{t-1}$ is the price of the last time period.

\subsection{Vector Autoregression (VAR) Model}

The VAR model (Sims, 1980) is used in order to estimate the effects of oil shocks on output/economic growth in oil exporting economies. The main advantage of VAR model is that it allows all the endogenous variables to interact among themselves in the economy; and estimates the effect and long run impacts of shocks to each variable on itself and other variables. Therefore, the VAR model is particularly important in this research to estimate the effects of oil price shocks on inflation, GDP growth, investment rate and exchange rate. The following VAR model is applied in this study.

$$
Y_{t}=C+\sum_{t=1}^{n} \Phi_{t} Y_{t}+\beta_{t} X_{t}+\varepsilon_{t} \ldots \ldots \ldots \ldots \ldots \text {.eq. } 3
$$

Where $Y_{t}$ is a $(\mathrm{nx} 1)$ vector of endogenous variables, $\mathrm{C}$ is a $(\mathrm{nx} 1)$ vector of constants, $\Phi_{t}$ is a $(n \times n)$ matrix of coefficients, $\mathrm{i}=1,2, \ldots \ldots \ldots, \mathrm{n}$ is the number of lags and $\varepsilon_{t}$ is $(\mathrm{nx} 1)$ vector of error terms in time t. In eq.3, $X_{t}$ represents oil price shocks as exogenous variable and $\beta_{t}$ is the coefficient of oil price shocks in time t. Due to the inclusion of $\beta_{t} X_{t}$ component in eq. 3 the VAR Model is now termed as the VARX model with oil shocks as the exogenous variable.

\section{Descriptive Statistics}

Table 2 below presents the descriptive statistics for GDP growth, inflation rate, investment rate, exchange rate and oil shocks for Algeria, Iran, Kuwait, Nigeria, Saudi Arabia and Venezuela. 
Table 2: Descriptive Statistics

\begin{tabular}{|c|c|c|c|c|c|}
\hline \multicolumn{6}{|c|}{ ALGERIA } \\
\hline Variable & Mean & Median & Std. Dev. & Skewness & Kurtosis \\
\hline GDP growth & -0.135715 & 0 & 1.53393 & -0.849783 & 1.93391 \\
\hline Inflation & -0.0336042 & 0.0847368 & 2.52253 & 0.402974 & 2.3839 \\
\hline Investment & 0.00935987 & 0.00802797 & 0.221921 & 0.302222 & -1.01168 \\
\hline Exchange rate & 0.0908484 & 0.040875 & 0.723811 & 2.2899 & 6.25906 \\
\hline \multicolumn{6}{|c|}{ IRAN } \\
\hline Variable & Mean & Median & Std. Dev. & Skewness & Kurtosis \\
\hline GDP growth & -0.0797111 & -0.013636 & 1.50132 & -0.17784 & 0.415912 \\
\hline Inflation & 0.00364738 & -0.000748268 & 1.43475 & 0.249197 & 0.74751 \\
\hline Investment & -0.000451925 & 0.00435526 & 0.664646 & -0.537516 & 2.10461 \\
\hline Exchange rate & 0.166441 & 0.0192912 & 2.96217 & 4.16406 & 17.0238 \\
\hline \multicolumn{6}{|c|}{ KUWAIT } \\
\hline Variable & Mean & Median & Std. Dev. & Skewness & Kurtosis \\
\hline GDP growth & -0.179996 & 0 & 1.75325 & -0.0547097 & 1.0045 \\
\hline Inflation & 0.0736592 & 0.0530785 & 3.1384 & 0.881617 & 2.32872 \\
\hline Investment & 0.00855955 & 0.0188791 & 0.90649 & 0.588885 & 2.52054 \\
\hline Exchange rate & 0.00145582 & 0.00131255 & 0.068142 & 0.211693 & 0.354759 \\
\hline \multicolumn{6}{|c|}{ NIGERIA } \\
\hline Variable & Mean & Median & Std. Dev. & Skewness & Kurtosis \\
\hline GDP growth & -0.0836578 & -0.0780081 & 3.21888 & -0.130257 & 2.73414 \\
\hline Inflation & -0.0208733 & 0.0220731 & 1.57446 & -0.158577 & 0.36285 \\
\hline Investment & 0.00678547 & 0.0377413 & 0.433997 & -0.105485 & 0.0902499 \\
\hline Exchange rate & 0.173212 & 0.0710816 & 1.43961 & 2.58907 & 6.85443 \\
\hline \multicolumn{6}{|c|}{ SAUDI ARABIA } \\
\hline Variable & Mean & Median & Std. Dev. & Skewness & Kurtosis \\
\hline GDP growth & -0.065985 & 0 & 4.89279 & -0.00644593 & 1.84622 \\
\hline Inflation & -0.000105518 & 0 & 2.1549 & -0.753557 & 1.83372 \\
\hline Investment & 0.00602792 & 0.0102975 & 0.303085 & -0.107571 & -0.320174 \\
\hline Exchange rate & 0.00321557 & 0 & 0.0275208 & 2.17149 & 3.41206 \\
\hline \multicolumn{6}{|c|}{ VENEZUELA } \\
\hline Variable & Mean & Median & Std. Dev. & Skewness & Kurtosis \\
\hline GDP growth & -0.273999 & 0 & 3.5169 & -0.682009 & 3.10828 \\
\hline Inflation & 0.0162685 & -0.075405 & 1.05301 & 0.495817 & -0.362572 \\
\hline Investment & 0.00439478 & 0.0548934 & 0.603303 & -0.671785 & 1.0909 \\
\hline Exchange rate & 0.226289 & 0.160313 & 0.872351 & 1.25762 & 0.897836 \\
\hline Oil shock & 0.0578615 & 0.0198421 & 0.490968 & 3.11004 & 10.496 \\
\hline
\end{tabular}




\section{Augmented Dickey - Fuller (ADF) test}

To determine the effects of oil shocks on macroeconomic variables (exchange rate, GDP growth, investment and inflation), it is necessary to test whether the variables used in the study are stationary and integrated of the same order. Thus, the ADF unit root test has been employed for establishing the Stationarity for all the time series (GDP growth, inflation, exchange rate and investment) used in the analysis. The following model is used by the ADF test:

$$
\Delta Y_{t}=\beta_{\circ}+\beta_{1} Y_{t-1}+\beta_{2} \Delta Y_{t-1}+\varepsilon_{t \ldots \ldots \ldots \ldots . . . e q .4}
$$

Table 3 below reports the ADF test results of five variables used in this research.

Table 3: The results for Augmented Dickey - Fuller test

\begin{tabular}{|c|c|c|c|c|c|c|c|c|c|c|}
\hline \multirow{2}{*}{ Countries } & \multicolumn{2}{|c|}{ GDP growth } & \multicolumn{2}{c|}{ Inflation } & \multicolumn{2}{c|}{ Investment } & \multicolumn{2}{|c|}{ Exchange rate } & \multicolumn{2}{c|}{ Oil price } \\
\cline { 2 - 12 } & t-Stat & Prob. & t-Stat & Prob. & t-Stat & Prob. & t-Stat & Prob. & t-Stat & Prob. \\
\hline Algeria & -6.771 & 0.000 & -7.956 & 0.000 & -6.101 & 0.000 & -7.243 & $0.000^{*}$ & -6.095 & 0.000 \\
\hline Iran & -2.585 & 0.096 & -3.255 & 0.017 & -7.091 & $0.000^{*}$ & -5.221 & 0.000 & & \\
\hline Kuwait & -5.596 & 0.000 & -2.685 & 0.077 & -3.877 & 0.002 & -5.969 & 0.000 & & \\
\hline Nigeria & -5.975 & 0.000 & -4.936 & $0.000^{*}$ & -4.071 & 0.001 & -4.805 & 0.001 & & \\
\hline Saudi Arabia & -4.978 & $0.000^{*}$ & -5.794 & 0.000 & -5.143 & 0.000 & -7.915 & 0.000 & & \\
\hline Venezuela & -5.966 & 0.000 & -5.718 & 0.000 & -3.389 & 0.011 & -6.116 & 0.000 & & \\
\hline * Stationary at First Difference & & \multicolumn{10}{|c|}{} & & & & & \\
\hline
\end{tabular}

The ADF test results indicate that the null hypothesis of non-Stationarity is rejected for all the time series included in the study. As per the p-value for all the time series included in the data is smaller than the critical value 0.05 and this implies that the series are stationary at 5\% significance level, with the exception of GDP growth in Iran and inflation in Kuwait being stationary at 10\%. All the variables are stationary in levels except investment in Iran, inflation in Nigeria and GDP growth in Saudi Arabia are stationary at first difference. This indicates that apart from investment in Iran, inflation in Nigeria and GDP growth in Saudi Arabia, all the five variables included in the analysis are integrated of order I (1).

\section{Empirical Results}

The VARX model results for GDP growth, inflation, investment and exchange rate are presented in table 4, table 5, table 6 and table 7 respectively in Appendix I.

The VARX results for GDP Growth in Table 4 (Appendix I) reveal that oil shocks effects are found to be significant for Algeria and Venezuela. These shocks are found 
to affect negatively the GDP growth of Algeria whereas positive effects are found for Venezuela. Considering the effects of lagged values, GDP growth in Algeria, Iran, Nigeria and Saudi Arabia is affected by its first lag significantly and it's also affected by the first lag of inflation and exchange rates in Iran and by the lag of investment rate in Venezuela and Nigeria.

In Table 5 (Appendix I) the VARX results for inflation indicate that oil shocks affect inflation only in Venezuela and Iran. The effect of oil shocks in Venezuela on its inflation rate is negative whereas it's positive in Iran. Moreover in Venezuela inflation is also affected by its first lag and by the lagged values of exchange rates.

The VARX results given in Table 6 reveal that oil shocks do not affect significantly the investment rates in any of the understudy OPEC economy. However investment rates are affected by lagged exchange rates in Iran and Venezuela. Moreover investment rates are also found to affect GDP Growth in Saudi Arabia.

Similarly the results given in Table 7, exhibit that the oil shocks do not affect exchange rate in any of the OPEC economy understudy. However lagged exchange rates do affect the current exchange rates in Algeria and Saudi Arabia. Such results are attributable to the fact that the oil is traded in dollar hence the home exchange rates are not affected by the dollar shocks in oil prices.

\section{Conclusion}

This research investigated the effects of oil price shocks on economic/output growth of oil exporting economies. In this study the annual data on four macroeconomic indicators (inflation, GDP growth, exchange rate and investment) of six OPEC economies have been used for analysis over the period 1980 to 2013. The empirical findings of the study suggest that oil price shock has significant negative effect on Algerian GDP growth which negates the study conducted by Bouchaour and Al-Zeaud (2012). Moreover, the study indicated significant positive impact of oil shock on GDP growth of Venezuela. This result supports the studies conducted by Ito (2008 and 2010), Umar and AbdulHakeem (2010). However, the results for rest of the countries are statistically insignificant and supporting the study conducted by Olomola (2006).

The findings pertaining to the significant relationship between oil price shocks and inflation rate in Iran have been supported by the studies carried out by Ito (2008 and 2010); Lorde, Jackman and Thomas (2009), Arinze (2011), Bouchaour and Al-Zeaud (2012); Shaari, Hussain and Abdullah (2012). Moreover, the findings of the study reveal that the effect of oil shock on inflation rate is statistically significant negative at the $10 \%$ level in Venezuela. On the other hand, the results for the remaining countries are statistically insignificant which supports the study conducted by Olomola (2006). 
Furthermore in accordance with the work of Farzanegan and Markwardt (2009) and Garkaz, Azma and Jafari (2012), the empirical findings of study indicate that oil price shocks have no major impact on the investment rates in the understudy economies.

The empirical results for the effect of oil price shock on the exchange rate of all the countries are statistically insignificant. The findings are contrary to previous researches carried out by Olomola (2006, Nikbakht (2010), Bouchaour and Al-Zeaud (2012).

For future research work it is recommended that the scope of the study might be extended in many ways, the study suggests to conduct similar research with extending the sample period, applying different models, using different frequency data (monthly or quarterly), changing the number of variables as macroeconomic indicators and including more lags in order to see the impact again.

\section{References}

Adedokun, A. J. (2012). Oil Export and Economic Growth: Descriptive Analysis and Empirical Evidence from Nigeria. Pakistan Journal of Social Sciences, Vol. 9(1), pp. 46-58.

Arinze, P. E. (2011). The impact of oil price on the Nigerian economy. Journal of Research in National Development (JORIND), Vol.9 (1), pp. 211-215.

Berument, M. H., Ceylan, N. B. \& Dogan, N. (2010). The impact of oil price shocks on the economic growth of selected MENA countries. The Energy Journal, Vol. 31(1), pp. 149-176.

Bouchaour, C. \& Al-Zeaud, H. A. (2012). Oil Price Distortion and Their Impact on Algerian Macroeconomic. International Journal of Business and Management, Vol. 7(18), pp.99-114.

Curwen, P. J. (1976). Inflation. California: Macmillan Press.

Eltejaei, E. \& Afzali, M.A. (2012). Asymmetric Impacts of Oil Prices and Revenues Fluctuations on Selected Macroeconomic Variables in Iran. Journal of Basic and Applied Scientific Research, Vol. 2(8), pp. 7930-7937.

Farzanegan, M. R. \& Markwardt, G. (2009). The effects of oil price shocks on the Iranian economy. Energy Economics, Vol. 31, pp. 134-151.

Garkaz, M., Azma, F. \& Jafari, R. Relationship between oil revenues and government expenditure using wavelet analysis method: Evidence from Iran. Economics and Finance Review,Vol. 2(5) pp. 52 - 61.

Ghalayini, L. (2011). The Interaction between Oil Price and Economic Growth. Middle Eastern Finance and Economics, (13), 127-140.

Ito, K. (2008). Oil Prices and Macro-economy in Russia: The Co-integrated VAR Model Approach. International Applied Economics and Management Letters, Vo. 1(1), pp 37-40.

Ito, K. (2010). Oil price and macroeconomy in Russia. Economics Bulletin, Vol. 17(17), pp. 1-9. 
Jawad, M. (2013). Oil Price Volatility and its impact on Economic Growth in Pakistan. Journal of Finance and Economics, Vol. 1(4), pp. 62-68.

Jimenez-Rodriguez, R. and Sanchez, M. (2005). Oil price shocks and real GDP growth: empirical evidence for some OECD countries. Applied economics, Vol. 37(2), pp. 201-228.

Lorde, T., Jackman, M. \& Thomas, C. (2009). The macroeconomic effects of oil price fluctuations on a small open oil-producing country: the case of Trinidad and Tobago. Energy Policy, Vol. 37, pp. 2708-2716.

Mehrara, M. \& Dehkarsalari, A.R. (2011). OIL REVENUES AND ECONOMIC GROWTH IN IRAN. Economics and Finance Review, Vol. 1(5) pp. 44 - 56.

Mehrara, M. (2008). The asymmetric relationship between oil revenues and economic activities: The case of oil-exporting countries. Energy Policy, Vol. 36, pp. 1164-1168.

Mehrara, M., Maki, M. \& Tavakolian, H. (2010). The relationship between oil revenues and economic growth, using threshold methods (the case of Iran). OPEC Energy Review, Vol. 34(1), pp. 1-14.

Mendoza, O. \& Vera, D. (2010). The asymmetric effects of oil shocks on an oil-exporting economy. Cuadernos De Economía, Vol. 47(135), pp. 3-13.

Mohammad, S. D. (2010). The Impact of Oil Prices Volatility on Export Earning in Pakistan. European Journal of Scientific Research, Vol. 41(4), pp.543-550.

Monjazeb, M., Souri, A. \& Shahabi, Z. (2013). The effect of oil price shocks on economic growth (Case Study; Selected Oil Exporting Countries). Technical Journal of Engineering and Applied Sciences, Vol. 3 (17), pp. 2118-2122.

Mordi, C. N. \& Adebiyi, M. A. (2010). The Asymmetric Effects of Oil Price Shocks on Output and Prices in Nigeria using a Structural VAR Model. CENTRAL BANK OF NIGERIA, Vol. 48(1), pp. 1-32.

Mork, K. A. (1989). Oil and the macroeconomy when prices go up and down: an extension of Hamilton's results. The Journal of Political Economy, Vol. 97(3), pp. 740-744.

Nikbakht, L. (2010). Oil prices and exchange rates: the case of OPEC. Business Intelligence Journal, Vol. 3(1), pp. 83-92.

Olomola, P. A. (2006). Oil price shock and aggregate economic activity in Nigeria. African Economic and Business Review, Vol. 4(2), pp. 48-61.

Radcliffe, R. C. (1996), Investment: concepts, analysis, strategy (5th ed.). London: Harper Collins.

Rezazadehkarsalari, A., Haghiri, F. \& Behrooznia, A. (2013). The effects of oil price shocks on real GDP in Iran. African Journal of Business Management, Vol. 7(33), pp. 3220 - 3232.

Samimi, A. J. \& Shahryar, B. (2009). Oil Price Shocks, Output and Inflation: Evidence from Some OPEC Countries. Australian Journal of Basic and Applied Sciences, Vol. 3(3), pp.2791-2800.

Schirber, M. (2009). The Chemistry of Life: Oil's Many Uses. Retrieved October 20, 2013, from http:// 
www.livescience.com/5574-chemistry-life-oil.html

Shaari, M. S., Hussain, N. E. \& Abdullah, H. (2012). The Effects of Oil Price Shocks and Exchange Rate Volatility on Inflation: Evidence from Malaysia. International Business Research, Vol. 5(9), 106-112.

Tauline, M.J. (2008). Exchange Rates: Dynamics, Expectations and Adjustment. New York: Nova Science Pub Incorporated.

Umar, G. \& AbdulHakeem, K.A. (2010). Oil price shocks and the Nigeria economy: a variance autoregressive (VAR) model. International Journal of Business and Management, Vol. 5(8), pp. 39-49.

Weil, D. N. (2009). Economic Growth (2nd ed.). New Jersey: Pearson Education Inc.

\section{Appendix I}

Table 4: VARX Results for GDP Growth

\begin{tabular}{|c|c|c|c|c|c|}
\hline \multicolumn{6}{|c|}{ ALGERIA } \\
\hline & Coefficient & Std. Error & t-ratio & p-value & \\
\hline const & 0.0474247 & 0.166303 & 0.2852 & 0.77786 & \\
\hline GDP growth_1 & -0.315329 & 0.178642 & -1.7651 & 0.08975 & * \\
\hline Inflation_1 & -0.0931695 & 0.160093 & -0.582 & 0.5658 & \\
\hline Investment_1 & 1.2918 & 1.2404 & 1.0414 & 0.30764 & \\
\hline Exchange rate_1 & -0.827067 & 0.819317 & -1.0095 & 0.32243 & \\
\hline oil shock & -3.2145 & 1.27224 & -2.5266 & 0.01822 & ** \\
\hline R-squared & 0.255315 & & & & \\
\hline \multicolumn{6}{|c|}{ IRAN } \\
\hline & Coefficient & Std. Error & t-ratio & p-value & \\
\hline const & 0.0522878 & 0.144514 & 0.3618 & 0.72053 & \\
\hline GDP growth_1 & -0.511033 & 0.177376 & -2.8811 & 0.00802 & $* * *$ \\
\hline Inflation_1 & -0.739797 & 0.260966 & -2.8348 & 0.00895 & $* * *$ \\
\hline Investment_1 & -0.0967865 & 0.391664 & -0.2471 & 0.80684 & \\
\hline Exchange rate_1 & -0.429065 & 0.208956 & -2.0534 & 0.05064 & * \\
\hline oil shock & -1.64751 & 1.32724 & -1.2413 & 0.22602 & \\
\hline R-squared & 0.390309 & & & & \\
\hline \multicolumn{6}{|c|}{ KUWAIT } \\
\hline & Coefficient & Std. Error & t-ratio & $\mathrm{p}$-value & \\
\hline const & -0.291717 & 0.17669 & -1.651 & 0.11077 & \\
\hline GDP growth_1 & -0.126855 & 0.198694 & -0.6384 & 0.52877 & \\
\hline
\end{tabular}




\begin{tabular}{|c|c|c|c|c|c|}
\hline Inflation_1 & -0.0405293 & 0.167629 & -0.2418 & 0.81085 & \\
\hline Investment_1 & 0.985141 & 0.548839 & 1.795 & 0.0843 & * \\
\hline Exchange rate_1 & -5.73728 & 5.83198 & -0.9838 & 0.3343 & \\
\hline oil shock & 1.62372 & 1.6023 & 1.0134 & 0.32022 & \\
\hline R-squared & 0.178332 & & & & \\
\hline \multicolumn{6}{|c|}{ NIGERIA } \\
\hline & Coefficient & Std. Error & t-ratio & $\mathrm{p}$-value & \\
\hline const & 0.0892384 & 0.225109 & 0.3964 & 0.69516 & \\
\hline GDP growth_1 & -0.491117 & 0.146967 & -3.3417 & 0.00262 & *** \\
\hline Inflation_1 & -0.242764 & 0.260854 & -0.9307 & 0.36093 & \\
\hline Investment_1 & -2.51331 & 1.03512 & -2.428 & 0.02271 & $* *$ \\
\hline Exchange rate_1 & 0.414989 & 0.589819 & 0.7036 & 0.48819 & \\
\hline oil shock & -2.62576 & 1.92513 & -1.3639 & 0.18474 & \\
\hline R-squared & 0.399103 & & & & \\
\hline \multicolumn{6}{|c|}{ SAUDI ARABIA } \\
\hline & Coefficient & Std. Error & t-ratio & p-value & \\
\hline const & -0.000670493 & 0.422926 & -0.0016 & 0.99875 & \\
\hline GDP growth_1 & -0.480299 & 0.181395 & -2.6478 & 0.01383 & $* *$ \\
\hline Inflation_1 & 0.306228 & 0.363627 & 0.8421 & 0.40769 & \\
\hline Investment_1 & -4.15887 & 2.75223 & -1.5111 & 0.1433 & \\
\hline Exchange rate_1 & -1.36172 & 51.6317 & -0.0264 & 0.97917 & \\
\hline oil shock & -1.284 & 4.10019 & -0.3132 & 0.75676 & \\
\hline R-squared & 0.246425 & & & & \\
\hline \multicolumn{6}{|c|}{ VENEZUELA } \\
\hline & Coefficient & Std. Error & t-ratio & p-value & \\
\hline const & -0.767967 & 0.406207 & -1.8906 & 0.07033 & * \\
\hline GDP growth_1 & -0.0689486 & 0.207315 & -0.3326 & 0.74222 & \\
\hline Inflation_1 & -0.00526397 & 0.680985 & -0.0077 & 0.99389 & \\
\hline Investment__1 & -1.35863 & 0.752488 & -1.8055 & 0.08305 & * \\
\hline Exchange rate_1 & 0.426677 & 1.27902 & 0.3336 & 0.74147 & \\
\hline oil shock & 5.57521 & 2.48819 & 2.2407 & 0.03417 & $* *$ \\
\hline R-squared & 0.283162 & & & & \\
\hline
\end{tabular}


Table 5: VARX Results for Inflation

\begin{tabular}{|c|c|c|c|c|c|}
\hline \multicolumn{6}{|c|}{ ALGERIA } \\
\hline & Coefficient & Std. Error & t-ratio & p-value & \\
\hline const & 0.0348467 & 0.20017 & 0.1741 & 0.8632 & \\
\hline GDP growth_1 & -0.019363 & 0.215023 & -0.0901 & 0.92896 & \\
\hline Inflation_1 & -0.329279 & 0.192695 & -1.7088 & 0.09988 & * \\
\hline Investment_1 & -1.00353 & 1.493 & -0.6722 & 0.50765 & \\
\hline Exchange rate_1 & 0.335175 & 0.986171 & 0.3399 & 0.73679 & \\
\hline oil shock & -1.30719 & 1.53134 & -0.8536 & 0.40142 & \\
\hline R-squared & 0.181239 & & & & \\
\hline \multicolumn{6}{|c|}{ IRAN } \\
\hline & Coefficient & Std. Error & t-ratio & p-value & \\
\hline const & -0.137603 & 0.118549 & -1.1607 & 0.25672 & \\
\hline GDP growth_1 & 0.119828 & 0.145506 & 0.8235 & 0.418 & \\
\hline Inflation_1 & 0.127731 & 0.214078 & 0.5967 & 0.5561 & \\
\hline Investment_1 & -0.0201009 & 0.321293 & -0.0626 & 0.95061 & \\
\hline Exchange rate_1 & 0.165488 & 0.171412 & 0.9654 & 0.34357 & \\
\hline oil shock & 2.20153 & 1.08877 & 2.022 & 0.054 & * \\
\hline R-squared & 0.162831 & & & & \\
\hline \multicolumn{6}{|c|}{ KUWAIT } \\
\hline & Coefficient & Std. Error & t-ratio & $\mathrm{p}$-value & \\
\hline const & 0.183276 & 0.218147 & 0.8402 & 0.40848 & \\
\hline GDP growth_1 & 0.121435 & 0.245313 & 0.495 & 0.62474 & \\
\hline Inflation_1 & -0.0438148 & 0.20696 & -0.2117 & 0.83399 & \\
\hline Investment_1 & 0.170362 & 0.677611 & 0.2514 & 0.80347 & \\
\hline Exchange rate_1 & 3.57717 & 7.20032 & 0.4968 & 0.6235 & \\
\hline oil shock & -1.63473 & 1.97824 & -0.8264 & 0.41612 & \\
\hline R-squared & 0.053554 & & & & \\
\hline \multicolumn{6}{|c|}{ NIGERIA } \\
\hline & Coefficient & Std. Error & t-ratio & $\mathrm{p}$-value & \\
\hline const & -0.0506015 & 0.170605 & -0.2966 & 0.76922 & \\
\hline
\end{tabular}




\begin{tabular}{|c|c|c|c|c|c|}
\hline GDP growth_1 & -0.164572 & 0.111383 & -1.4775 & 0.15202 & \\
\hline Inflation_1 & 0.0105406 & 0.197695 & 0.0533 & 0.9579 & \\
\hline Investment_1 & -0.579423 & 0.784492 & -0.7386 & 0.46703 & \\
\hline Exchange rate_1 & 0.419322 & 0.44701 & 0.9381 & 0.35719 & \\
\hline oil shock & -0.429036 & 1.45901 & -0.2941 & 0.77114 & \\
\hline R-squared & 0.123594 & & & & \\
\hline \multicolumn{6}{|c|}{ SAUDI ARABIA } \\
\hline & Coefficient & Std. Error & t-ratio & $\mathrm{p}$-value & \\
\hline const & 0.0624378 & 0.228728 & 0.273 & 0.78711 & \\
\hline GDP growth_1 & -0.0141361 & 0.0981028 & -0.1441 & 0.88658 & \\
\hline Inflation_1 & 0.0658826 & 0.196658 & 0.335 & 0.74041 & \\
\hline Investment_1 & -0.159818 & 1.48847 & -0.1074 & 0.91535 & \\
\hline Exchange rate_1 & -20.0746 & 27.9236 & -0.7189 & 0.47886 & \\
\hline oil shock & 0.624205 & 2.21748 & 0.2815 & 0.78065 & \\
\hline R-squared & 0.027481 & & & & \\
\hline \multicolumn{6}{|c|}{ VENEZUELA } \\
\hline & Coefficient & Std. Error & t-ratio & p-value & \\
\hline const & 0.458731 & 0.11549 & 3.9721 & 0.00053 & $* * *$ \\
\hline GDP growth_1 & 0.0350887 & 0.0589422 & 0.5953 & 0.55699 & \\
\hline Inflation_1 & 0.495147 & 0.193613 & 2.5574 & 0.01699 & ** \\
\hline Investment_1 & -0.0321092 & 0.213942 & -0.1501 & 0.8819 & \\
\hline Exchange rate_1 & -1.54632 & 0.363642 & -4.2523 & 0.00026 & $* * *$ \\
\hline oil shock & -1.34216 & 0.707423 & -1.8972 & 0.0694 & * \\
\hline R-squared & 0.460838 & & & & \\
\hline
\end{tabular}


Table 6: VARX Results for Investment

\begin{tabular}{|c|c|c|c|c|c|}
\hline \multicolumn{6}{|c|}{ ALGERIA } \\
\hline & Coefficient & Std. Error & t-ratio & p-value & \\
\hline const & 0.0181204 & 0.0300807 & 0.6024 & 0.55234 & \\
\hline GDP growth_1 & -0.0141033 & 0.0323127 & -0.4365 & 0.66625 & \\
\hline Inflation_1 & 0.0341144 & 0.0289575 & 1.1781 & 0.24986 & \\
\hline Investment_1 & -0.0984185 & 0.224363 & -0.4387 & 0.66468 & \\
\hline Exchange rate_1 & -0.138975 & 0.148198 & -0.9378 & 0.35733 & \\
\hline oil shock & 0.053965 & 0.230123 & 0.2345 & 0.8165 & \\
\hline R-squared & 0.115337 & & & & \\
\hline \multicolumn{6}{|c|}{ IRAN } \\
\hline & Coefficient & Std. Error & t-ratio & p-value & \\
\hline const & 0.0431561 & 0.0541545 & 0.7969 & 0.43301 & \\
\hline GDP growth_1 & 0.105913 & 0.066469 & 1.5934 & 0.12363 & \\
\hline Inflation_1 & -0.040537 & 0.0977931 & -0.4145 & 0.68203 & \\
\hline Investment_1 & -0.287659 & 0.14677 & -1.9599 & 0.06124 & * \\
\hline Exchange rate_1 & -0.137754 & 0.0783031 & -1.7592 & 0.09077 & * \\
\hline oil shock & 0.264013 & 0.497364 & 0.5308 & 0.60022 & \\
\hline R-squared & 0.26328 & & & & \\
\hline \multicolumn{6}{|c|}{ KUWAIT } \\
\hline & Coefficient & Std. Error & t-ratio & p-value & \\
\hline const & -0.000422607 & 0.0620016 & -0.0068 & 0.99461 & \\
\hline GDP growth_1 & 0.0204918 & 0.0697227 & 0.2939 & 0.77116 & \\
\hline Inflation_1 & -0.0188681 & 0.058822 & -0.3208 & 0.75095 & \\
\hline Investment_1 & -0.18833 & 0.192591 & -0.9779 & 0.33715 & \\
\hline Exchange rate_1 & 1.82115 & 2.04647 & 0.8899 & 0.38168 & \\
\hline oil shock & 0.125286 & 0.562255 & 0.2228 & 0.82541 & \\
\hline R-squared & 0.090248 & & & & \\
\hline \multicolumn{6}{|c|}{ NIGERIA } \\
\hline & Coefficient & Std. Error & t-ratio & $\mathrm{p}$-value & \\
\hline const & 0.0151684 & 0.0422489 & 0.359 & 0.72259 & \\
\hline
\end{tabular}




\begin{tabular}{|c|c|c|c|c|c|}
\hline GDP growth_1 & 0.0400634 & 0.027583 & 1.4525 & 0.15881 & \\
\hline Inflation_1 & 0.0393204 & 0.0489576 & 0.8032 & 0.42946 & \\
\hline Investment_1 & 0.153703 & 0.194273 & 0.7912 & 0.43629 & \\
\hline Exchange rate_1 & -0.18867 & 0.110698 & -1.7044 & 0.10071 & \\
\hline oil shock & 0.439521 & 0.361312 & 1.2165 & 0.23517 & \\
\hline R-squared & 0.22145 & & & & \\
\hline \multicolumn{6}{|c|}{ SAUDI ARABIA } \\
\hline & Coefficient & Std. Error & t-ratio & $\mathrm{p}$-value & \\
\hline const & 0.011159 & 0.0291407 & 0.3829 & 0.70501 & \\
\hline GDP growth_1 & 0.0289778 & 0.0124986 & 2.3185 & 0.02889 & ** \\
\hline Inflation_1 & -0.0327083 & 0.0250549 & -1.3055 & 0.20362 & \\
\hline Investment_1 & 0.168469 & 0.189636 & 0.8884 & 0.3828 & \\
\hline Exchange rate_1 & -3.96642 & 3.55757 & -1.1149 & 0.27549 & \\
\hline oil shock & 0.127964 & 0.282514 & 0.4529 & 0.65449 & \\
\hline R-squared & 0.246723 & & & & \\
\hline \multicolumn{6}{|c|}{ VENEZUELA } \\
\hline & Coefficient & Std. Error & t-ratio & p-value & \\
\hline const & -0.18238 & 0.100612 & -1.8127 & 0.0819 & * \\
\hline GDP growth_1 & 0.0263862 & 0.0513489 & 0.5139 & 0.61186 & \\
\hline Inflation_1 & -0.305511 & 0.16867 & -1.8113 & 0.08213 & * \\
\hline Investment_1 & -0.118204 & 0.186381 & -0.6342 & 0.53171 & \\
\hline Exchange rate_1 & 0.722806 & 0.316795 & 2.2816 & 0.03129 & ** \\
\hline oil shock & 0.486254 & 0.616289 & 0.789 & 0.43753 & \\
\hline R-squared & 0.199106 & & & & \\
\hline
\end{tabular}

Table 7: VARX Results for Exchange Rate

\begin{tabular}{|l|c|c|c|c|c|}
\hline \multicolumn{7}{|c|}{ ALGERIA } \\
\hline & Coefficient & Std. Error & t-ratio & p-value & \\
\hline const & 0.0604642 & 0.0381883 & 1.5833 & 0.12592 & \\
\hline GDP growth_1 & -0.0608777 & 0.0410219 & -1.484 & 0.1503 & \\
\hline Inflation_1 & 0.0122549 & 0.0367623 & 0.3334 & 0.74165 & \\
\hline Investment_1 & -0.158343 & 0.284834 & -0.5559 & 0.58321 & \\
\hline
\end{tabular}




\begin{tabular}{|c|c|c|c|c|c|}
\hline Exchange rate_1 & 0.393994 & 0.188141 & 2.0941 & 0.04655 & ** \\
\hline oil shock & -0.226565 & 0.292147 & -0.7755 & 0.44531 & \\
\hline $\mathrm{R}$-squared & 0.264253 & & & & \\
\hline \multicolumn{6}{|c|}{ IRAN } \\
\hline & Coefficient & Std. Error & t-ratio & $\mathrm{p}$-value & \\
\hline const & 0.229383 & 0.135485 & 1.6931 & 0.10287 & \\
\hline GDP growth_1 & -0.241833 & 0.166293 & -1.4543 & 0.15832 & \\
\hline Inflation_1 & -0.0828125 & 0.244661 & -0.3385 & 0.73783 & \\
\hline Investment_1 & 0.0414016 & 0.367193 & 0.1128 & 0.91113 & \\
\hline Exchange rate_1 & 0.0246679 & 0.1959 & 0.1259 & 0.9008 & \\
\hline oil shock & -1.34877 & 1.24432 & -1.0839 & 0.28873 & \\
\hline R-squared & 0.10581 & & & & \\
\hline \multicolumn{6}{|c|}{ KUWAIT } \\
\hline & Coefficient & Std. Error & t-ratio & $\mathrm{p}$-value & \\
\hline const & 0.00365109 & 0.00597124 & 0.6114 & 0.54621 & \\
\hline GDP growth_1 & 0.00196997 & 0.00671484 & 0.2934 & 0.77156 & \\
\hline Inflation_1 & 0.00197959 & 0.00566503 & 0.3494 & 0.72957 & \\
\hline Investment_1 & -0.0142181 & 0.018548 & -0.7666 & 0.45025 & \\
\hline Exchange rate_1 & -0.0293931 & 0.197091 & -0.1491 & 0.8826 & \\
\hline oil shock & -0.0494808 & 0.0541496 & -0.9138 & 0.36923 & \\
\hline R-squared & 0.048624 & & & & \\
\hline \multicolumn{6}{|c|}{ NIGERIA } \\
\hline & Coefficient & Std. Error & t-ratio & $\mathrm{p}$-value & \\
\hline const & 0.117815 & 0.0699701 & 1.6838 & 0.10467 & \\
\hline GDP growth_1 & -0.00854927 & 0.0456814 & -0.1872 & 0.85305 & \\
\hline Inflation_1 & 0.109372 & 0.0810808 & 1.3489 & 0.18945 & \\
\hline Investment_1 & 0.630829 & 0.321744 & 1.9607 & 0.06115 & * \\
\hline Exchange rate_1 & -0.00114083 & 0.183332 & -0.0062 & 0.99508 & \\
\hline oil shock & 0.952225 & 0.598384 & 1.5913 & 0.1241 & \\
\hline R-squared & 0.226842 & & & & \\
\hline & & & & & \\
\hline
\end{tabular}




\begin{tabular}{|c|c|c|c|c|c|}
\hline \multicolumn{6}{|c|}{ SAUDI ARABIA } \\
\hline & Coefficient & Std. Error & t-ratio & p-value & \\
\hline const & 7.62E-05 & 0.000904157 & 0.0843 & 0.9335 & \\
\hline GDP growth_1 & $2.33 \mathrm{E}-05$ & 0.000387798 & 0.0602 & 0.95249 & \\
\hline Inflation_1 & -0.000396532 & 0.000777384 & -0.5101 & 0.61447 & \\
\hline Investment_1 & 0.0071647 & 0.00588388 & 1.2177 & 0.23471 & \\
\hline Exchange rate_1 & 0.833986 & 0.110382 & 7.5555 & $<0.00001$ & *** \\
\hline oil shock & 0.00015088 & 0.00876565 & 0.0172 & 0.9864 & \\
\hline R-squared & 0.733428 & & & & \\
\hline \multicolumn{6}{|c|}{ VENEZUELA } \\
\hline & Coefficient & Std. Error & t-ratio & $\mathrm{p}$-value & \\
\hline const & 0.345151 & 0.0796508 & 4.3333 & 0.00021 & $* * *$ \\
\hline GDP growth_1 & 0.016644 & 0.0406512 & 0.4094 & 0.68571 & \\
\hline Inflation_1 & 0.0754949 & 0.133531 & 0.5654 & 0.57686 & \\
\hline Investment_1 & -0.149209 & 0.147551 & -1.0112 & 0.32159 & \\
\hline Exchange rate_1 & -0.307724 & 0.250796 & -1.227 & 0.23126 & \\
\hline oil shock & -0.684651 & 0.487894 & -1.4033 & 0.17283 & \\
\hline R-squared & 0.15554 & & & & \\
\hline
\end{tabular}


